\title{
Sources of paratyphoid Salmonella in the production chain of broilers in the Northern mesoregion of Maranhão State, Brazil
}

\section{Fontes de salmonelas paratíficas na cadeia produtiva de frangos de corte da mesorregião Norte do Estado do Maranhão, Brasil}

\author{
Daniela Aguiar Penha Brito ${ }^{1 *}$; Gracielle Lopes Almeida Sousa ${ }^{2}$; \\ Yara Lima de Souza ${ }^{3}$; Vanessa Reis ${ }^{3}$; Jéssica Ravane de Sousa Silva ${ }^{3}$; \\ Adriana Reis ${ }^{3}$; Alexandre $\mathrm{Oba}^{4}$
}

\begin{abstract}
Highlights
Paratyphoid Salmonella are present in the broiler chain in Maranhão.

Newly slaughtered carcasses were the main source of contamination by Salmonella spp.

Salmonella serovar Schwarzengrund was predominant in the poultry production chain.

The artisanal poultry slaughter can increase dissemination of Salmonella spp.
\end{abstract}

\begin{abstract}
Paratyphoid Salmonella significantly impacts modern poultry farming, because it is one of the main causes of foodborne diseases in the world. Efforts have been made by the government and poultry industry to reduce the existence of Salmonella in the entire poultry production chain through sanitary programs. The aim of this work was to investigate the occurrence of Salmonella spp. and its serovars in environmental sources of production, poultry, and carcasses slaughtered in an artisanal manner in the northern mesoregion of Maranhão State, Brazil. A total of 520 samples were collected, comprising drag swabs $(n=60)$, prope $(n=60)$, cecal feces $(n=60)$, feed of feeder $(n=60)$, and cloacal swabs $(n=100)$ of poultry sent for slaughter, and newly slaughtered carcasses $(n=180)$. The samples were subjected to culture and isolation of Salmonella spp. and serotyping. The occurrence of the genus Salmonella was $25.0 \%(15 / 60)$ in drag swabs, $16.6 \%(10 / 60)$ in prope, $1.7 \%(1 / 60)$ in cecal feces, absent $(0 / 60)$ in the feed, $7 \%(7 / 100)$ in cloacal swabs, and $48.9 \%(88 / 180)$ in poultry carcasses. Fifteen Salmonella enterica serovars were identified in the samples, with the highest occurrence in the Schwarzengrund $(28.09 \%$; 34/121), Albany $(19.83 \% ; 24 / 121)$, Enteritidis $(7.43 \% ; 9 / 121)$, and Heidelberg $(7.43 \%$; 9/121). Salmonella ser. Schwarzengrund showed higher predominance in the poultry production chain, with greater isolation in carcass samples (34 isolates), while Salmonella ser. Enteritidis had the highest occurrence in the initial production chain. The results of our study indicate the need to implement sanitary control in farms for paratyphoid salmonella and that artisanal poultry slaughter can increase bacterial dissemination in the final product, representing a public health risk.

Key words: Carcass. Poultry Farming poultry farms. Salmonella Schwarzengrund. salmonellosis.
\end{abstract}

${ }^{1}$ Prof $^{a}$, Instituto Federal de Educação, Ciência e Tecnologia do Maranhão, IFMA, São Luís, Brasil. E-mail: danielabrito@ifma. edu.br

2 Discente, Curso em Licenciatura em Ciências Agrárias, Instituto Federal de Educação, Ciência e Tecnologia do Maranhão, IFMA, São Luís, MA, Brasil. E-mail: gracielle85@hotmail.com

3 Discentes, Curso Técnico em Agropecuária, IFMA, São Luís, MA, Brasil.E-mail: yaralimasz.yl@gmail.com; vanessa04rengav@ gmail.com; sousaravane@gmail.com; reisadriana07@gmail.com

4 Prof. Dr., Universidade Estadual de Londrina, Centro de Ciências Agrárias, Departamento de Zootecnia, UEL, Londrina, PR, Brasil. E-mail: oba@uel.br

* Author for correspondence 
As salmonelas paratíficas causam grande impacto para avicultura moderna, por se tratar de uma das principais causas de doenças de origem alimentar no mundo. Há um esforço de órgãos governamentais e da indústria avícola em diminuir a presença da Salmonella em toda cadeia produtiva de aves, através de programas sanitários. O objetivo desse trabalho foi pesquisar a ocorrência da Salmonella spp. e seus sorovares em fontes ambientais de produção, em aves e em carcaças abatidas de forma artesanal na Mesorregião Norte do Estado do Maranhão, Brasil. Foram coletadas 240 amostras de suabe de arrasto, propé, fezes cecais e ração de comedouros, 100 amostras de suabes de cloaca de aves destinadas ao abate e 180 amostras de carcaças recém abatidas. As amostras foram submetidas a cultura e isolamento de Salmonella spp. e sorotipificação. A ocorrência do gênero Salmonella foi de 25,0\% (15/60) em suabe de arrasto, $16,6 \%(10 / 60)$ de propé, $1,7 \%(1 / 60)$ em fezes cecais, ausência $(0 / 60)$ em ração, $7 \%$ (7/100) de suabe cloacal e 48,9\% (88/180) em carcaças de frango. Foram identificados 15 sorovares de Salmonella enterica nas amostras, sendo os de maior ocorrência: Schwarzengrund (28,09\%; 34/121), Albany $(19,83 \% ; 24 / 121)$, Enteritidis $(7,43 \% ; 9 / 121)$ e Heidelberg $(7,43 \% ; 9 / 121)$. Salmonella ser. Schwarzengrund apresentou maior predominância na cadeia produtiva de aves, com maior isolamento em amostras de carcaça (34 isolados) enquanto Salmonella ser. Enteritidis teve maior ocorrência na cadeia inicial de produção. Os resultados encontrados indicam a necessidade de implementação do controle sanitário nas granjas para as salmonelas paratíficas e que o abate artesanal de aves pode aumentar a disseminação da bactéria no produto final, representando risco para saúde pública.

Palavras-chave: Avicultura. Carcaça. Granjas. Salmonella Schwarzengrund. Salmonelose.

\section{Introduction}

Salmonella enterica remains the main enteric bacterium causing food-borne diseases worldwide (ANDINO; HANNING, 2015; CDC, 2011). Among the various hosts, birds are considered important reservoirs of salmonella serovars capable of causing diseases in humans, and poultry products are the main carriers through which microorganisms enter into the food chain (CARDOSO; TESSARI, 2008).

The consumption of chicken meat has progressively increased. It is considered dominant in the diet of Brazilians and is the second most consumed meat in the world (FAO, 2015; USDA, 2016). The increase in demand for this product has allowed the development and consolidation of the poultry industry in several countries, such as Brazil, a leader in the production and exportation of chicken meat (ABPA, 2017). On the other hand, the consumption of chicken products has become a risk factor due to the occurrence of salmonellosis in humans (WHO/FAO, 2009). The high-density production system coupled with high susceptibility of chickens to colonization by Salmonella spp. in the intestinal tract has favored dissemination of bacteria and persistence in the poultry production chain, becoming a problem in the poultry farming industry worldwide (ANDREATTI FILHO et al., 2009; VOLKOVA et al., 2009).

The use of biosecurity programs is the main means of controlling and keeping farming systems free from being the sources of diseases that cause economic impact and are a risk to public health. However, with regard to salmonellosis, disease control is difficult because of the complex epidemiology, involving a wide variety of serovars without specific hosts, which enables countless reservoirs and several sources of environmental contamination (CARDOSO et al., 2013; FOLEY et al., 2013). Knowledge of Salmonella occurrence and circulating serovars in farms or lots assists in the establishment of more specific and effective measures in disease control (REVOLLEDO, 2008).

Avian paratyphoid is avian salmonellosis with the highest risk for poultry farming, especially because of its negative effects on public health (CARDOSO et al., 2013). In this kind of salmonellosis, the non- 
exclusive serovars of birds are included, which cause subclinical infections, being able to remain in the gastrointestinal tract of chickens until slaughter (ANDINO; HANNING, 2015; BERCHIERI JÚNIOR et al., 2009). Among the paratyphoid salmonella, Salmonella enterica serovar Enteritidis and Salmonella enterica serovar Typhimurium are the major causes of diseases associated with eggs and chicken meat consumption. The control of these bacteria is one of the criteria for sanitary certification of poultry establishments in Brazil, as recommended by the National Plan of Poultry Health of the Ministry of Agriculture, Livestock and Supply, which guarantees sanitary quality and safety of the food produced in the country (BRASIL, 2003).

In the industry, the presence of Salmonella spp. in chicken carcasses is through initial transmittance between birds themselves, and the presence of the bacterium in the chicken intestine is the main risk factor for meat contamination (AARESTRUP et al., 2007; HUE et al., 2011). Slaughter operations and successive processes may result in meat cross-contamination and its by-products (VON RÜCKERT et al., 2009). The conditions of hygiene of slaughterhouses and slaughter techniques applied are determinant factors for disseminating Salmonella spp. in the carcasses (LUNDGREN et al., 2009).

Studies conducted in Brazil show large variations in the prevalence and distribution of Salmonella serovars in poultry carcasses originating from slaughterhouses (BONI et al., 2011; CARDOSO et al., 2015; DUARTE et al., 2009; MINHARRO et al., 2015; MOREIRA et al., 2008). Most of the research is conducted in the south, southeast and midwest regions, where there is the highest concentration of birds in the confinement system and slaughterhouses under federal inspection service (RAVAGNANI et al., 2012). The Brazilian poultry industry continues to expand to northern and southern regions of Brazil, with the implementation of commercial establishments, but with few chicken meat-processing industries. Epidemiological studies on Salmonella spp. in farms and poultry products in these regions are scarce, where poultry slaughter in a small scale is still a common practice. Hence, considering the socioeconomic losses caused by Salmonella spp. and the risks to public health, the aim of this study was to investigate the sources of contamination and infection by Salmonella spp. and determine their serovars in the broiler production chain in the northern mesoregion of Maranhão State, Brazil.

\section{Materials and methods}

\section{Sample size}

The research was carried out in the northern mesoregion of Maranhão State, represented by the microregions of Itapecuru-Mirim and urban areas of São Luís. In the production chain sector, the research was concentrated on poultry farms, poultry distribution warehouses, and artisanal slaughterhouses of municipal public markets, because there was no industrial poultry slaughterhouse with sanitary inspection in the State.

\section{Sampling}

During 2013 to 2014, 240 samples from 60 aviaries containing batches of poultry aged between 35 and 45 days were collected and analyzed. The aviaries had from 15,500 to 32,000 birds, in an airconditioned and semi-air-conditioned system, and rice husk was used as poultry litter and reutilized for up to three lots.

From each aviary, samples were collected from two swabs of avian litter, four sterilized propes, 200 grams of fresh cecal feces, and 300 grams of feed from the feeder, following guidelines of Ministry of Agriculture, Livestock and Supply (BRASIL, 2013). The avian bed swabs were collected from water fountains and feeders, with the aid of sterilized propes, then, assembled in a single sample 
per aviary, and packaged in bottles containing 0.1 $\%$ peptone buffered water. Samples of fresh cecal feces (pasty and of greenish brown in color) were harvested at different points distributed along the shed, and assembled as a single sample, using spatulas and sterile collectors. As for the feed, each sample consisted of randomly collected portions in 12 feeders located on the lateral and center of the aviary, then placed in a sterile and homogenized collector (MAPA/OPAS, 2010).

Samples were collected from the poultry transportation vehicles of five warehouses, through cloacal swabs of 1000 birds of different batches, which were housed in cages, at the time of distribution to the slaughterhouses. Each sample of cloacal swab corresponded to a pool of 10 local swabs, totaling 100 samples.

Twenty public markets that represented a conglomerate were drawn and then samples of broiler carcasses were collected from artisan slaughterhouses in the morning, totaling 180 samples of whole carcasses. Samples harvested shortly after slaughter were packaged in sterile polyethylene bags, identified, and transported in a box of isothermal material containing recyclable ice and analyzed not more than 2 hours after collection.

\section{Microbiological analysis}

The samples were processed at the Microbiology Laboratory of the Federal Institute of Education, Science and Technology of Maranhão (FIMA). It began with the pre-enrichment of the samples, in which the cloacal and drag swabs of avian bed were immediately incubated at $37^{\circ} \mathrm{C}$ for 18 to 20 hours. Stool and feed samples were weighed $(25 \mathrm{~g})$ and diluted in $225 \mathrm{~mL}$ of $1 \%$ buffered peptone water, homogenized, and incubated at $37^{\circ} \mathrm{C}$ for 18 to 20 hours. The poultry carcasses were analyzed by the rinse technique, with the use of $300 \mathrm{~mL} 1 \%$ buffered peptone water (COX, 1978). The solution obtained was transferred, aseptically, to a sterile container and incubated under the same conditions as other samples.

For research on Salmonella, the samples were subjected to an enrichment step in the proportion 1:10 in Selenite-Cystine Broth $(1 \mathrm{ml} / 10 \mathrm{ml})$ and $1: 100$ in Rappaport Vassiliadis Broth $(0.1 \mathrm{ml} / 10$ $\mathrm{ml}$ ), and then incubated at $42^{\circ} \mathrm{C}$ for 18 to 24 hours. Subsequently, the samples were seeded in selective medium indicators: xylose lysine deoxycholate (XLD) agar, brilliant green phenolred lactose sucrose (BPLS) agar, SalmonellaShigella (SS) agar, and Hektoen enteric (HE) agar. After incubation at $37^{\circ} \mathrm{C}$ for 24 hours, the colonies suspected of Salmonella spp. were isolated and subjected to biochemical tests in Triple Sugar Iron (TSI) agar, Lysine Iron (LIA) agar, SIM and Urea broth, following the methodology recommended by Ministry of Agriculture, Livestock and Supply (BRASIL, 1995). The strains that showed characteristic reactions of Salmonella in the TSI and LIA agars, mobile or immobile in SIM, negative for the indole and urease test were characterized antigenically by the rapid agglutination test with the somatic polyvalent antiserum $\left(\right.$ Probac $\left.^{\circledR}\right)$. Salmonella isolates were cultivated in nutrient agar and sent to the Enterobacteria Laboratory of Oswaldo Cruz Foundation Institute, Rio de Janeiro (IOC/ FIOCRUZ, RJ, BRASIL) for antigenic serotyping.

The research was approved by the Ethics Committee on the Use of Animals in Research of the Londrina State University (LSU) under number 15093.2014.96.

\section{Results and Discussion}

Salmonella spp. was isolated in all stages of the poultry production chain (Table 1). From the total of 520 samples analyzed, $121(23.26 \%)$ were positive for Salmonella spp. Of these, 7 (1.3\%) were of cloacal swab of birds, $26(5.0 \%)$ of samples from the poultry breeding environment, and $88(16.92 \%)$ of slaughterhouses samples. 
Table 1. Occurrence of Salmonella spp. in the broiler production chain of Maranhão State, 2013 to 2014.

\begin{tabular}{lccc}
\hline \multicolumn{1}{c}{ Sample types } & Sample size (n) & \multicolumn{2}{c}{ Presence of Salmonella } \\
\cline { 3 - 4 } & & $\boldsymbol{N}$ & \% \\
\hline Aviary samples & 60 & 15 & 25 \\
Drag Swab & 60 & 10 & 16.7 \\
Prope & 60 & 1 & 1.7 \\
Fresh stools & 60 & 0 & 0 \\
Feed & & & 7 \\
Poultry samples & 100 & 7 & \\
Cloacal Swab & & & 48.9 \\
Slaughterhouse samples & 180 & 88 & 23.3 \\
Chicken carcasses & 520 & 121 & \\
\hline Total & & & \\
\hline
\end{tabular}

By evaluating the samples of the poultry breeding environment, it was found that Salmonella spp. was isolated from $25 \%(15 / 60)$ in samples of drag swabs, $16.7 \%(10 / 60)$ in samples of prope, and $1.7 \%(1 / 60)$ in samples of cecal feces (Table 1). Salmonella spp. was not isolated in feed samples of feeders $(0 / 60)$.

It was found that 20 of 60 aviaries had the isolation of Salmonella spp. in some of the environmental samples analyzed, and the drag swabs showed the highest isolation rate, with $15 / 60$ positive samples $(25.0 \%)$. These results were superior to the work by Pandini et al. (2015), who found Salmonella in $11.4 \%$ of the samples of drag swabs of aviaries in Paraná, and by Andreatti Filho et al. (2009), who encountered occurrence of $2.7 \%$ aviaries of poultry farms in São Paulo.

The drag swab technique is an efficient method to evaluate the sanitary status of the poultry litter and indirectly of the poultry lot. The place where chickens rest is an important source of contamination by Salmonella spp., because it can accommodate a large number of bacteria for long periods of time, and if not treated properly, can transmit pathogenic agents to subsequent batches (SANTIN, 2014). The high occurrence of Salmonella spp. in samples of drag swabs indicates flaws in the sanitary control in production, requiring the implementation of biosecurity programs to control this bacterium. It is worth noting that the high contamination by Salmonella spp. in poultry litter is associated with increased isolation of the bacterium in poultry carcasses in slaughterhouses (VOLKOVA et al., 2010), possibly by increasing the external contamination of the chicken (feathers and skin) or the possibility of oral infection of the birds.

It was observed that bacterium isolates were low $(1 / 60)$ in cecal feces from the breeding environment of broilers, at the end of the production cycle. This result can be due to the fact that the infected birds, by some serovars of Salmonella spp., transmit the microorganism intermittently, which decreases with the advancing age of the birds, making them carriers (ANDRADE et al., 2007; BONI et al., 2011). The stress caused by catching and transporting birds causes a pathogen elimination increase by the feces of carrier poultry, increasing the isolation of Salmonella spp. before slaughter (MARIN; LAINEZ, 2009).

In poultry that arrived from transport vehicles, the occurrence of Salmonella in cloacal swabs was $7 \%(7 / 100)$ (Table 1). The results found were inferior to that of Chiu et al. (2010), who isolated Salmonella spp. in 17 (11.3\%) of 150 samples of 
cloacal swab of broilers that were three weeks of age. Different results were also found by Ravagnani et al. (2012), who did not isolate Salmonella spp. in 100 cloacal swabs of broilers with a mean age of 21 days, in the western region of Paraná. These authors suggest that the high sanitary control adopted by integrating companies influenced the absence of the bacterium in broilers.

It is noteworthy that the sampled birds were being destined to the region's slaughterhouses. Thus, the isolation of the bacterium in live birds, at slaughter stage, reveals the presence of the asymptomatic carrier, considered one of the most important epidemiological factors for the presence of Salmonella spp. in slaughterhouses (AARESTRUP et al., 2007; HUE et al., 2011). Cardoso and Tessari (2008) emphasize that a small number of animals infected with Salmonellas spp. that arrives at the slaughterhouse can cause contamination of the entire slaughter line, in places where the carcasses are not processed properly. Therefore, the higher the prevalence in live birds, the more the contamination in the carcasses slaughtered.

In this study, of the samples analyzed from the production chain of broilers, carcasses of slaughterhouses showed the highest isolation of Salmonella spp., with the occurrence of $48.9 \%$. These results were superior to those found in research evaluating carcasses in industrial slaughterhouses in Brazil in the last decade, in which they obtained a range from 2.5 to $25.49 \%$ (CARDOSO et al., 2015; DUARTE et al., 2009; MINHARRO et al., 2015; MOREIRA et al., 2008).

The high contamination rate of carcasses by Salmonella spp. may be attributed to various factors related to slaughtering and processing of meat in the regional slaughterhouses that were evaluated. It is known that market establishments and fairs are not suitable for slaughter of animals, because the infrastructure of the sites allows for the cross contamination of Salmonella spp., such as in the defeathering and manual evisceration. Studies indicate that the manual evisceration method may increase the risk of contamination by Salmonella spp. in slaughterhouses (RIVIERA-PEREZ et al., 2014). Once the bacteria are present in the intestine of birds, the lack of operator ability in the process of evisceration can disseminate the microorganism through utensils, equipment, and hands of operators (STOPPA, 2011).

The occurrence of Salmonella spp. in chicken meat tends to be higher in samples collected from artisanal slaughterhouses present in markets and fairs in Brazil (BARROS et al., 2014; BRITO et al., 2010; MOURA FILHO et al., 2010). Research carried out in other countries, where the artisanal slaughter of chickens is recorded in traditional city markets, indicate high rates of contamination by Salmonella spp. in chicken meat, which showed $62.5 \%$ in Senegal (BADA-ALAMBEDJI et al., 2006) 59\% in Taiwan (CHEN et al., 2010), and $48.75 \%$ in Pakistan (SHAH; KOREJO, 2012). The authors attribute the high occurrence of the bacterium to the population's low socioeconomic level and the precarious sanitary hygiene conditions of poultry slaughterhouses.

The predominant requirement for ensuring the sanitary quality of chicken meat is hygiene. It was observed that the occurrence of Salmonella spp. in the slaughterhouse's samples (48.88\%) was almost seven times higher than the occurrence in live birds (7.0\%). The deficient sanitary hygiene measures applied in the physical area the operators, in addition to the meat processing practices, may have contributed significant transmission and increase in the presence of the bacterium in the samples evaluated.

Although the poultry industry in Brazil is a world reference in the production and exportation of chicken meat, the slaughter of poultry in small scale is still a common practice in the north and northeast regions of the country, enabling the emergence of numerous artisanal slaughterhouses. Poultry farming, which for many years has developed in the 
south and southeast regions, has been expanding to these regions with the implantation of integration systems of farms and the emergence of industrial slaughterhouses, but still fail to meet the demands of the regional market.

The serotyping of 121 isolates identified 15 Salmonella enterica serovars (Table 2). In 15 isolates, Salmonella enterica subspecies enterica was identified with the following antigenic formulas: O:4,5 (9/121), O:6,8 (3/121), O:3,10 (2/121) and O:4,5:I,v:-(1/121). Salmonella enterica serovar Schwarzengrund was found to be more frequent $(28.09 \%)$ in the poultry production chain and was isolated in five environmental samples, two birds, and 27 slaughterhouses. Salmonella enterica serovar Albany was the second with the highest occurrence $(19.83 \%)$, and isolated in a sample of prope and 23 carcasses of slaughterhouses. Salmonella ser. Enteritidis appeared in $7.43 \%$ of the isolates, which was found in seven environmental samples and two bird samples. With equal isolation rate, Salmonella enterica serovar Heildelberg appeared exclusively in nine samples of slaughterhouses. There was isolation of Salmonella ser. Typhimurium in two samples of drag swab of the poultry farms.

Table 2. Distribution of serovars Salmonella spp. according to the occurrence and sources of isolation in the broiler production chain of Maranhão State, 2013 to 2014.

\begin{tabular}{lcccccccc}
\hline \multicolumn{1}{c}{$\begin{array}{c}\text { Serovars of } \\
\text { Salmonella enterica }\end{array}$} & $\begin{array}{c}\text { Drag } \\
\text { Swab }\end{array}$ & Prope & Stool & Ration & $\begin{array}{c}\text { Cloacal } \\
\text { Swab }\end{array}$ & \multirow{2}{*}{ Housing } & \multicolumn{2}{c}{ Isolated } \\
\hline Schwarzengrund & 4 & 1 & - & - & 2 & 27 & 34 & 28,09 \\
Albany & - & 1 & - & - & - & 23 & 24 & 19,83 \\
Enteritidis & 3 & 4 & - & - & 2 & - & 9 & 7,43 \\
Heidelberg & - & - & - & - & - & 9 & 9 & 7,43 \\
O:4,5 & 2 & 2 & - & - & - & 5 & 9 & 7,43 \\
Panama & - & - & 1 & - & - & 5 & 6 & 4,95 \\
Kentucky & 1 & - & - & - & 1 & 3 & 5 & 4,13 \\
Munich & - & 1 & - & - & 1 & 3 & 5 & 4,13 \\
O:6,8 & - & - & - & - & - & 3 & 3 & 2,47 \\
Hadar & 1 & - & - & - & - & 2 & 3 & 2,47 \\
Agona & - & 1 & - & - & 1 & 1 & 3 & 2,47 \\
Typhimurium & 2 & - & - & - & - & - & 2 & 1,65 \\
Derby & - & - & - & - & - & 2 & 2 & 1,65 \\
O:3,10 $*$ & 1 & - & - & - & - & 1 & 2 & 1,65 \\
Orion & - & - & - & - & - & 1 & 1 & 0,82 \\
Anatum & - & - & - & - & - & 1 & 1 & 0,82 \\
Stenftenberg & - & - & - & - & - & 1 & 1 & 0,82 \\
Worthing & - & - & - & - & - & 1 & 1 & 0,82 \\
O:4,5:I,v:- & 1 & - & - & - & - & - & 1 & 0,82 \\
\hline Total & 15 & 10 & 1 & - & 7 & 88 & 121 & 100 \\
\hline
\end{tabular}

*Undetectable flagellar structure. 
It was found that Salmonella ser. Enteritidis showed higher occurrence in environmental and poultry samples, and was not isolated in slaughterhouse samples (Table 2). Cardoso et al. (2013) and Scur et al. (2014) confirmed this serovar to be more prevalent in samples of poultry breeding environment in the southeast and southern regions of the country, respectively. It is known that Salmonella ser. Enteritidis has been described as the main serovar isolated in batches of chickens, poultry meat, and commercial eggs in the last decade in Brazil (BONI et al., 2011; BRASIL, 2012; CARDOSO et al., 2015; DUARTE et al., 2009; MEDEIROS et al., 2011; MINHARRO et al., 2015). This serovar along with Salmonella ser. Typhimurium have significant impact on public health, because they have high pathogenicity for human beings, and are mainly responsible for outbreaks through food worldwide (RICKE et al., 2013). Furthermore, because they are associated with poultry products, specific control programs for these serovars were implemented, along with sanitary monitoring of the stocks and incentive for vaccination against Salmonella ser. Enteritidis as a means to reduce the vertical transmission of the agent. In some Brazilian states, there was a reduction or absence of Salmonella ser. Enteritidis in samples collected from poultry farms (MENDONÇA, 2011; RAVAGNANI et al., 2012; VOSS-RECH et al., 2015), from which it has been inferred that there have been improvements in the sanitary control of this serovar in hatchery and farms.

The presence of salmonella ser. Enteritidis and Salmonella ser. Typhimurium in samples of farms and poultry indicate failure in the execution of sanitary programs, because the control of these agents is considered fundamental for the sanitary certification through the National Poultry Health Plan (NPHP) (BRASIL, 2003). According to Silva and Duarte (2002), the control and eradication of these serovars throughout the country is hindered by the little or no impact on the productivity of the birds added with the little awareness that the eradication of these pathogens from farms will cause a reduction in outbreaks in humans.

In our study, Salmonella ser. Schwarzengrund was more prevalent in samples of chicken carcasses, being isolated in 27 of 180 samples (Table 2). This serovar was also the most prevalent in the poultry production chain $(28.81 \%)$, occurring in samples of drag swab, prope, and cloacal swab. These results corroborate the data by Moraes et al. (2014) who found the same serovar as the most prevalent $(28.3 \%)$ in the poultry production chain of Goiás State. Higher rates of isolation were found by Boni et al. (2011), which verified the occurrence of $37.93 \%$ in the production chain of Mato Grosso do Sul State, and by Chen et al. (2010), who found that $33.5 \%$ of serovar was present in chicken meat in public markets in Taiwan.

The dynamism of paratyphoid salmonella serovar of avian origin in a country may be influenced by regional characteristics such as climate and seasons (VALCHEVA et al., 2011; YANG et al., 2013), by socio-economic Factors (SHAH; KOREJO, 2012), for the import or export of food and animal products (AARESTRUP et al., 2007), and mainly by the implementation of sanitary programs (FOLEY et al., 2011). The gradual dominance substitution of Salmonella ser. Enteritidis by other paratyphoid salmonella serovars in Brazilian broiler production and in slaughterhouses has been reported (MUNIZ, 2012; VOSS-RECH et al., 2015). In the present study, Salmonella ser. Schwarzengrund presented a higher predominance in the poultry production chain. The increased immunity of poultry caused by exposure or specific vaccinations against Salmonella ser. Enteritidis or against antigenically similar serovars has allowed the decline of this serovar and occupation of other paratyphoid serovars in their ecological niche (FOLEY et al., 2011).

In the last ten years, Salmonella ser. Schwarzengrund is described as one of the most frequent serovars of Salmonella spp. isolated from broilers and poultry products in Asia, Europe and 
the United States (AARESTRUP et al., 2007; ANDINO; HANNING, 2015; ASAI et al., 2009; CHEN et al., 2010; USDA, 2015). Similarly, this serovar has been recorded in the poultry production chain in Brazil and is found in all regions of the country (MENDONÇA, 2011; MOREIRA et al., 2008; PANDINI et al., 2015; VOSS-RECH et al., 2015). Although Salmonella ser. Schwarzengrund is a less common cause of human salmonellosis, with higher incidence of cases in the Asian continent (CHEN et al., 2010) and in the United States (CDC, 2007), it is emphasized that this serovar could be the reason because of its increase in the poultry production chain, emphasizing its impact in the poultry farming, because it is an emerging serovar that has negative effects on public health.

Salmonella ser. Albany stands out as the serovar with the second highest occurrence, isolated almost exclusively in chicken carcasses. Brito et al. (2010) also detected this serovar in $12.5 \%$ of newly slaughtered chicken carcasses in markets of Maranhão State. Despite being considered as a rare serovar and often associated with chicken meat in other countries (CHEN et al., 2010; ELGROUD et al., 2015; THAI et al., 2012; ZAIDI et al., 2006), in Brazil, the presence of Salmonella ser. Albany in chicken carcasses is commonly recorded in industrial slaughterhouses (MOREIRA et al., 2008; PANZENHAGEN et al., 2016; STOPPA, 2011). Poultry and wild animals are the main reservoirs of this serovar (SILVA-HIDALGO et al., 2013). The contamination found in carcasses by Salmonella ser. Albany may pose a risk to consumers, since it is an agent that causes food-borne diarrhea in humans (ZAIDI et al., 2006).

Another serovar of importance found in the evaluated carcasses was Salmonella ser. Heidelberg. In the order of impact of agents on humans, this agent is stands third and causes human salmonellosis in the United States (CDC, 2013) and grows in products of poultry (COLLA et al., 2012; MEDEIROS et al., 2011; USDA, 2015; VOSS-RECH et al., 2015). The presence of Salmonella ser. Heidelberg in marketed foods becomes worrisome, because this serovar is capable of causing invasive infections with greater severity in relation to other paratyphoid serovars (FOLEY et al., 2011).

The results found confirm the presence of paratyphoid salmonella in the broiler production chain of Maranhão State. Implementation of sanitary control in poultry farms in the region is needed and the artisanal slaughter of chickens can increase Salmonella spp. dissemination to carcasses, representing a risk to public health.

Paratyphoid salmonella are important pathogens found in food that are commonly disseminated by poultry products. The monitoring of this agent in the poultry production chain is fundamental for the promotion of public health, because it is one of the main etiological agents of food-borne diseases in the world.

\section{Acknowledgements}

We thank the Foundation for Research and Scientific and Technological Development of Maranhão (FAPEMA), the Coordination for the Improvement of Higher Education Personnel (CAPES), and the Federal Institute of Education, Science and Technology of Maranhão (IFMA) for financing the research.

\section{References}

AARESTRUP, F. M.; HENDRIKSEN, R. S.; LOCKETT, J.; GAY, K.; TEATES, K.; McDERMOTT, P. F.; WHITE, D. G.; HASMAN, H.; SORENSEN, G.; BANGTRAKULNONTH, A.; PORNREONGWONG, S.; PULSRIKARN, C.; ANGULO, F. J.; GERNERSMIDT, P. International spread of multidrug-resistant Salmonella Schwarzengrund in food products. Emerging Infectious Diseases, Atlanta, v. 13, n. 3, p. 726-731, maio 2007. DOI: 10.3201/eid1305.061489

ANDINO, A.; HANNING, I. Salmonella enterica: survival, colonization, and virulence differences among serovars. The Scientific World Journal, London, v. 2015, Article ID 520179, p. 1-15, 2015. DOI: $10.1155 / 2015 / 520179$ 
ANDRADE, M. A. A.; MESQUITA, A. J. de; STRINGHINI, J. H.; CHAVES, L. S.; MATTOS, M. S.; OLIVEIRA, A. S. C.; MORAES, D. M. C. Excreção fecal de Salmonella Enteritidis em duas linhagens de frangos de corte. Ciência Animal Brasileira, Goiânia, v. 8, n. 4, p. 757-765, 2007. Disponível em: https://revistas. ufg.br/vet/article/view/2697. Acesso em: 10 de outubro de 2018 .

ANDREATTI FILHO, R. L.; LIMA, E. T.; MENCONI, A.; ROCHA, T. S.; GONÇALVES, G. A. M. Pesquisa de Salmonella spp. em suabes de arrasto provenientes de granjas avícolas. Veterinária e Zootecnia, Botucatu, v. 16, n. 1, p. 190-194, 2009.

ASAI, T.; MURAKAMI, K.; OZAWA, M.; KOIKE, R.; ISHIKAWA, H. Relationships between multidrugresistant Salmonella enterica Serovar Schwarzengrund and both broiler chichens and retail chickens and retail chicken meats in Japan. Japanese Journal of Infectious Diseases, Tokyo, v. 62, n. 3, p. 198-2000, 2009.

ASSOCIAÇÃO BRASILEIRA DE PROTEÍNA ANIMAL - ABPA. Relatório Anual de 2016. São Paulo: ABPA, 2017. Disponível em: http://www. brazilianchicken.com.br/home/publicacoes. Acesso em: 1 jun. 2017.

BADA-ALAMBEDJI, R.; FOFANA, A.; SEYDI, M.; AKAKPO, A. J. Antimicrobial resistance of Salmonella isolated from poultry carcasses in Dakar (Senegal). Brazilian Journal of Microbiology, São Paulo, v. 37 , n. 4, p. $510-515$, 2006. DOI: $10.1590 / \mathrm{S} 1517-$ 83822006000400020

BARROS, L. S. S.; RIBEIRO, J. G. N.; CASELLI, J. B. Salmonella spp. Lignieres 1900 (Enterobacteriales: Enterobacteriaceae) in informally sold broilers. Revista Brasileira de Higiene e Sanidade Animal, Fortaleza, v. 8, n. 4, p. 1-21, 2014. DOI: 10.5935/1981-2965.20140130

BERCHIERI JÚNIOR, A.; FREITAS NETO, O. C. Salmoneloses. In: BERCHIERI JÚNIOR, A.; SILVA, E. N.; DI FÁBIO, J.; SESTI, L.; ZUANAZE, M. A. F. Doença das aves. Campinas: FACTA, 2009. p. 435-454.

BONI, H. F. K.; CARRIJO, A. S.; FASCINA, V. B. Ocorrência de Salmonella spp. em aviários e abatedouro de frangos de corte na região central de Mato Grosso do Sul. Revista Brasileira de Saúde e Produção Animal, Salvador, v. 12, n. 1, p. 84-95, 2011.

BONI, H. F. K.; CARRIJO, A. S.; FASCINA, V. B. Ocorrência de Salmonella spp. em aviários e abatedouro de frangos de corte na região central de Mato Grosso do Sul. Revista Brasileira de Saúde e Produção Animal, Salvador, v.12, n.1, p.84-95, 2011.
BRASIL. Ministério da Agricultura, Pecuária e do Abastecimento. Instrução Normativa $n^{\circ} 10$, de 11 de abril de 2013. Programa de gestão de risco diferenciado, baseado em vigilância epidemiológica e adoção de vacinas, para os estabelecimentos avícolas considerados de maior susceptibilidade à introdução e disseminação de agentes patogênicos no plantel avícola nacional e para estabelecimentos avícolas que exerçam atividades que necessitam de maior rigor sanitário. Diário Oficial [da] União, Brasília, 12 abr. 2013. Seção 1, p. 2.

BRASIL. Ministério da Agricultura, Pecuária e do Abastecimento. Instrução Normativa $\mathrm{n}^{\circ} 78$, de 3 de novembro de 2003. Normas Técnicas para Controle e Certificação de Núcleos e Estabelecimentos Avícolas como Livres de Salmonella Gallinarum e de Salmonella Pullorum e Livres ou Controlados para Salmonella Enteritidis e para Salmonella Typhimurium. Diário Oficial [da] União, Brasília, 5 nov. 2003. Seção 1, p. 3.

BRASIL. Ministério da Agricultura, Pecuária e do Abastecimento. Portaria DSA n ${ }^{\circ} .8$, de 23 de janeiro de 1995. Método Analítico de Carcaças de Aves e Pesquisa de Salmonella. Diário Oficial [da] União, Brasília, 10 out. 1995. Seção 1, p. 10.

BRASIL. Ministério da Saúde. Agência Nacional de Vigilância Sanitária - ANVISA. Programa Nacional de Monitoramento da Prevalência e da Resistência Bacteriana em Frango - PREBAF. Relatório de Pesquisa em Vigilância Sanitária de Alimentos. Monitoramento da prevalência e do perfil de suscetibilidade aos antimicrobianos em enterococos e salmonelas isolados de carcaças de frango congeladas comercializadas no Brasil. Brasília: ANVISA, 2012. 171 p. Disponível em: http://portal.anvisa.gov.br/wps/content/Anvisa+ Portal/ Anvisa/Inicio/Alimentos/Assuntos+de+ Interesse/ Monitoramento+e+Pesquisa/PREBAF. Acesso em: 10 abr. 2014.

BRITO, D. A. P.; ALVES, L. M. C.; COSTA, F. N. Detecção de Salmonella Albany, Staphylococcus coagulase positivos e micro-organismos mesófilos em carcaças de frango in natura. Arquivos do Instituto Biológico, São Paulo, v. 77, n. 1, p. 149-152, 2010.

CARDOSO, A. L. S. P.; KANASHIRO, A. M. I.; STOPPA, G. F. Z.; CASTRO, A. G. M. de; LUCIANO, R. L. Ocorrência de Salmonella spp. em carcaças de frango provenientes de abatedouros do estado de São Paulo, Brasil, no período de 2000 a 2010. Revista Científica Eletrônica de Medicina Veterinária, Garça, Ano 13, n. 24, p. 1-12, jan. 2015.

CARDOSO, A. L. S. P.; KANASHIRO, A. M. I.; STOPPA, G. F. Z.; CASTRO, A. G. M.; LUCIANO, R. L.; TESSARI, E. N. C. Prevalência de Salmonella 
Enteritidis isoladas de suabes de arrasto em granjas de frangos de corte. Revista Cientifica Eletrônica de Medicina Veterinária, Garça, Ano 11, n. 20, p. 1-15, jan. 2013.

CARDOSO, A. L. S. P.; TESSARI, E. N. C. Salmonela na segurança dos alimentos. Biológico, São Paulo, v. 70, n. 1, p. 11-13, jan./jun. 2008.

CENTER FOR DISEASE CONTROL AND PREVENTION - CDC. Estimatives of foodborne illness in the United States. Atlanta: CDC, 2011. Available at: http://www.cdc.gov/foodborneburden/2011-foodborneestimates.html. Accessed at: 10 nov. 2015.

CENTER FOR DISEASE CONTROL AND PREVENTION - CDC. Salmonella Schwarzengrund outbreak investigation. Atlanta: CDC, aug. 2007. Available at: http://www.cdc.gov/Salmonella/ schwarzengrund.html. Accessed at: 21 apr. 2016.

CENTER FOR DISEASE CONTROL AND PREVENTION - CDC. Surveillance for foodborne disease outbreaks United States. Atlanta: CDC, 2013. (Annual Report, 2013). Available at: http://www.cdc. gov/ foodsafety/fdoss/data/annual-summaries/. Accessed at: 24 apr. 2016.

CHEN, M. H.; WANG, S. W.; HWANG, W. Z.; TSAI, S. J.; HSIH, Y. C.; CHIOU, C. S.; TSEN, H. Y. Contamination of Salmonella Schwarzengrund cells in chicken meat from traditional marketplaces in Taiwan and comparison of their antibiograms with those of the human isolates. Poultry Science, Savoy, v. 89, n. 2, p. 359-365, 2010. DOI: 10.3382/ps.2009-00001

CHIU, L. H.; CHIU, C. H.; HORN, Y. M.; CHIOU, C. S.; LEE, C. Y.; YEH, C. M.; YU, C. Y.; WU, C. P.; CHANG, C. C.; CHU, C. Characterization of 13 multidrug resistant Salmonella serovars from different broiler chickens associated with those of human isolates. BMC Microbiology, v. 10, n. 86, p. 1-10, 2010. DOI: 10.1186/1471-2180-10-86

COLLA, F. L.; RODRIGUES, L. B.; BORSOI, A.; DICKEL, E. L.; NASCIMENTO, V. P.; SANTOS, L. R. Isolamento de Salmonella Heidelberg em diferentes pontos da tecnologia de abate de frangos de corte. Arquivos do Instituto Biológico, São Paulo, v. 79, n. 4, p. 603-606, out./dez. 2012. DOI: 10.1590/S180816572012000400018

COX, N. A.; MERCURI, A. J.; TANNER, D. A.; CARSON, M. O.; THOMSON, J. E.; BAILEY, J. S. Effectiveness of sampling methods for Salmonella detection on processed broilers. Journal of Food Protection, Des Moines, v. 41, n. 5, p. 341-343, 1978. DOI: $10.4315 / 0362-028 \mathrm{X}-41.5 .341$
DUARTE, D. A. M.; RIBEIRO, A. R. R.; VASCONCELOS, A. M. M.; SANTOS, S. B.; SILVA, J. V. D.; ANDRADE, P. L. A.; FALCÃO, L. S. P. da C. de A. Occurrence of Salmonella spp. in broiler chicken carcasses and their susceptibility to antimicrobial agents. Brazilian Journal of Microbiology, São Paulo, v. 40 , n. 3 , p. 569-573, 2009. DOI: 10.1590/S151783822009000300020

ELGROUD, R.; GRANIER, S. A.; MARAULT, M.; KEROUANTON, A.; LEZZAR, A.; BOUZITOUNABENTCHOUALA, C.; BRISABOIS, A.; MILLEMANN, Y. Contribution of avian Salmonella enterica isolates to human salmonellosis cases in Constantine (Algeria). Biomed Research International, London, v. 2015, n. 352029, p. 1-8, 2015. DOI: 10.1155/2015/352029

FOLEY, S. L.; NAYAK, R.; HANNING, I. B.; RICKE, S. C. Population dynamics of Salmonella enterica serotypes in commercial egg and poultry production. Applied and Environmental Microbiology, Washington, v. 77, n. 13, p. 4273-4279, 2011. DOI: 10.1128/AEM.00598-11

FOLEY S. L.; JOHNSON, T. J.; RICKE, S. C.; NAYAK, R.; DANZEISEN, J. Salmonella pathogenicity and host adaptation in chicken-associated serovars. Microbiology and Molecular Biology Review. n.77, v.4, p.582-607, 2013. DOI:10.1128/MMBR.00015-13

FOOD AND AGRICULTURE ORGANIZATION OF THE UNITED NATIONS - FAO. Agriculture Outlook 2015. 20 ${ }^{\text {th }}$ ed. Paris: OECD-FAO Publishing, 2015. 148 p. Available at: www.fao.org/3/a-i4738e.pdf. Accessed at: 10 nov. 2015.

HUE, O.; LE BOUQUIN, S.; LALANDE, F.; ALLAIN, V.; ROUXEL, S.; PETETIN, I.; QUESNE, S.; LAISNEY, M.; GLOAGUEN, P.; PICHEROT, M.; SALVAT, G.; BOUGEARD, S.; CHEMALY, M. Prevalence of Salmonella spp. on broiler chicken carcasses and risk factors at the slaughterhouse in France in 2008. Food Control, Vurrey, v. 22, n. 8, p. 1158-1164, ago. 2011. DOI: 10.1016/j.foodcont.2011.01.009

LUNDGREN, P. U.; SILVA, J. A.; MACIEL, J. F.; FERNANDES, T. M. Perfil da qualidade higiênicosanitária da carne bovina comercializada em feiras livres e mercados públicos de João Pessoa - PB, Brasil. Alimentos e Nutrição, Araraquara, v. 20, n. 1, p. 113-119, 2009.

MARIN, C.; LAINEZ, M. Salmonella detection in feces during broiler rearing and after live transport to the slaughterhouse. Poultry Science, Savoy, v. 88, n. 9, p. 1999-2005, 2009. DOI: 10.3382/ps.2009-00040

MEDEIROS, M. A. N.; OLIVEIRA, D. C. N.; RODRIGUES, D. P.; FREITAS, D. R. C. Prevalence and 
antimicrobial resistance of Salmonella in chicken carcasses at retail in 15 Brazilian cities. Revista Panamericana de Salud Publica, Washington, v. 30, n. 6, p. 555-60, 2011. DOI: $10.1590 / \mathrm{s} 1020-49892011001200010$

MENDONÇA, E. P. Disseminação de Salmonella sp na cadeia produtiva de frango de corte. 2011. Dissertação (Mestrado em Ciências Veterinária) - Universidade Federal de Uberlândia, Faculdade de Medicina Veterinária, Uberlândia.

MINHARRO, S.; NASCIMENTO, C. A.; GALLETI, J. P.; MERISSE, T. J.; FEITOSA, A. C. F.; SANTOS, H. D.; DIAS, F. E. F.; SANTANA, E. S.; BALDANI, C. D.; ANDRADE, M. A. Antimicrobial susceptibility of Salmonella serovars isolated from edible offal and carcasses of slaughtered poultry in the state of Tocantins, Brazil. Semina: Ciências Agrárias, Londrina, v. 36, n. 4, p. 2661-2670, jul./ago. 2015. DOI: $10.5433 / 1679-0359.2015 \mathrm{v} 36 \mathrm{n} 4 \mathrm{p} 2661$

MINISTÉRIO DA AGRICULTURA, PECUÁRIA E ABASTECIMENTO / ORGANIZAÇÃO PANAMERICANA DA SAÚDE - MAPA/OPAS. Saúde pública veterinária - Centro Pan-Americano de Febre Aftosa. Manual veterinário para colheita e envio de amostras. Rio de Janeiro: PANAFTOSA - OPAS/OMS, 2010. $218 \mathrm{p}$.

MORAES, D. M. C.; ANDRADE, M. A.; REZENDE, C. S. M.; BARNABÉ, A. C. de S.; JAYME, V. de S.; NUNES, I. A.; BAPTISTA, D. de A. Fontes de infecção e perfil de suscetibilidade aos antimicrobianos de Salmonella sp. isoladas no fluxo de produção de frangos de corte. Arquivos Instituto Biológico, São Paulo, v. 81, n. 3, p. 195-201, 2014. DOI: 10.1590/1808-1657001092012

MOREIRA, G. N.; REZENDE, C. S. M.; CARVALHO, R. N.; MESQUITA, S. Q. P.; OLIVEIRA, A. N.; ARRUDA, M. L. T. Ocorrência de Salmonella sp. em carcaças de frangos abatidos e comercializados em municípios do estado de Goiás. Revista do Instituto Adolfo Lutz, São Paulo, v. 67, n. 2, p. 126-130, 2008.

MOURA FILHO, L. G. M.; BEZERRA, S. S.; BARROS, G. C.; MELO, H. M. G.; MENDES, E. S. Perfil microbiológico da carne de frangos abatidos artesanalmente e na indústria, comercializados na grande Recife-PE. Medicina Veterinária, Recife, v. 4, n. 1, p. 12 17, jan./mar. 2010.

MUNIZ, E. C. Atualidades no estudo das salmoneloses aviárias. In: SIMPÓSIO SUL DE AVICULTURA, 13., 2012, Chapecó. Anais... Chapecó: EMBRAPA Suínos e Aves, 2012. p. 13-26.

PANDINI, J. A.; PINTO, F. G. S.; MULlER, J. M.;
WEBER, L. D.; MOURA, A C. de. Ocorrência e perfil de resistência antimicrobiana de sorotipos de Salmonella spp. isolados de aviários do Paraná, Brasil. Arquivos do Instituto Biológico, São Paulo, v. 82, n.00200, p. 1-6, 2015. DOI: $10.1590 / 1808-1657000352013$

PANZENHAGEN, P. H. N.; AGUIAR, W. S.; FRASÃO, B. da S.; PEREIRA, V. L. A.; ABREU, D. L. C.; RODRIGUES, D. P.; NASCIMENTO, E. Prevalence and fluoroquinolones resistance of Campylobacter and Salmonella isolates from poultry carcasses in Rio de Janeiro Brazil. Food Control, Vurrey, v. 61, p. 243-247, 2016. DOI: $10.1016 / j$.foodcont.2015.10.002

RAVAGNANI, L. K.; AGOSTINIS, R. O.; OTUTUMI, L. K.; LIMA, E. T.; FERNANDES, J. I. M.; MARTINS, L. A. Pesquisa de Salmonella spp. em frangos de corte criados em galpões climatizados de uma integração na região Oeste do Paraná. Semina: Ciências Agrárias, Londrina, v. 33, n. 6, p. 2327-2336, nov./dez. 2012. DOI: $10.5433 / 1679-0359.2012 v 33 n 6 p 2327$

REVOLLEDO, L. Alternativas para o controle de Salmonella. In: SIMPÓSIO BRASIL SUL DE AVICUlTURA, 11, 2008, Chapecó. Anais... Chapecó: EMBRAPA suínos e aves, 2008, p. 95-109.

RICKE, S. C.; DUNKLEY, C. S.; DURANT, J. A. A review on development of novel strategies for controlling Salmonella Enteritidis colonization in laying hens: Fiberbased molt diets. Poultry Science, Savoy, v. 92, n. 2, p. 502-525, fev. 2013. DOI: 10.3382/ps.2012-02763

RIVIERA-PEREZ, W.; BÁRQUIO-CALVO, E.; ZAMORA-SANABRIA, R. Salmonella contamination risk points in broiler carcasses during slaughter line processing. Journal of Food Protection, Des Moines, v. 77, n. 12, p. 2031-2034, 2014. DOI: 10.4315/0362-028X. JFP-14-052

SANTIN, E. Salmoneloses-aumento da transmissão vertical e falhas de manejo de reprodutoras. In: SIMPÓSIO BRASIL SUL DE AVICULTURA, 15., 2014, Chapecó. Anais... Chapecó: EMBRAPA Aves e Suínos, 2014. p. 140-157.

SCUR, M. C.; PINTO, F. G. S.; BONA, E.A. M.; WEBER, L. D.; ALVES, L. F. A.; MOURA, A. C. Occurrence and antimicrobial resistance of Salmonella serotypes isolates recovered from poultry of Western Paraná, Brazil. African Journal of Agricultural Research, v.9, n.9, p. 823-830, 2014. DOI: 10.5897/AJAR2013.8202

SHAH, A. H.; KOREJO, N. A. Antimicrobial resistance profile of Salmonella serovars isolated from chicken meat. Turkish Journal Veterinary Animal Sciences, Kirikkale, v. 2, p. 40-46, 2012. 
SILVA, E. N.; DUARTE, A. Salmonella enteritidis em aves: retrospectiva no Brasil. Brazilian Journal of Poultry Science, Campinas, v. 4, n. 2, p. 85-100, maio/ ago. 2002. DOI: 10.1590/S1516-635X2002000200001

SILVA-HIDALGO, G.; LÓPEZ-MORENO, H. S.; ORTIZ-NAVARETE, F. O.; ARANDA-ALPUCHE, C.; RENDÓN-MALDONADO, J. G.; LÓPEZVALENZUELA, J. A.; LÓPEZVALENZUELA, M.; JUAREZ-BARRANCO, F. Prevalence of Salmonella enterica serovar Albany in captive zoo wild animals in the Culiacán Zoo in Mexico. Journal of Zoo and Wildlife Medicine, Yulee, v. 44, n. 1, p. 8-14, 2013. DOI: 10.1638/1042-7260-44.1.8

STOPPA, G. F. Z. Pesquisa de Salmonella spp. em abatedouros avícolas. 2011. Dissertação (Mestrado em Microbiologia Agropecuária) - Universidade Estadual Paulista, Faculdade de Ciências Agrárias e Veterinárias, Jaboticabal.

THAI, T. H.; HIRAI, T.; LAN, N. T.; YAMAGUCHI, R. Antibiotic resistance profiles of Salmonella serovars isolated from retail pork and chicken meat in North Vietnam. International Journal of Food Microbiology, Turin, v. 156, n. 2, p. 147-151, 2012. DOI: 10.1016/j. ijfoodmicro.2012.03.016

UNITED STATES DEPARTMENT OF AGRICULTURE - USDA. Food Safety and Inspection Service (FSIS). Serotypes Profile of Salmonella Isolates from Meat and Poultry Products January 1998 through December 2014. Washington: USDA, 2015. Available at: http://www.fsis. usda.gov. Accessed at: 24 abr. 2016.

UNITED STATES DEPARTAMENT OF AGRICULTURA - USDA. Trade of all meats to expand in 2016. Livestock and Poultry: World Markets and Trade, abr. 2016.

VALCHEVA, R.; BELOPOPSKA, P.; MATEVA, G.; HRISTOVA, T.; DASKALOV, H. Distribution and serological typing of Salmonella spp. isolates from broiler carcasses in Bulgaria. Bulgarian Journal of Veterinary Medicine, Stara Zagora, v. 14, n. 1, p. 31-38, 2011. DOI: http://tru.uni-sz.bg/bjvm/BJVM\%20March\% 202011\%20p.31-38.pdf

VOLKOVA, V. V.; BAILEY, R. H.; RYBOLT, M. L.; DAZO-GALARNEAU K.; HUBBARD, S. A.; MAGEE,
D.; BYRD, J. A.; WILL, R. W. Interrelationships of Salmonella status of flock and grow-out environment at sequential segments in broiler production and processing. Zoonoses and Public Health, Berlin, v. 57, n. 7-8, p. 463475, 2010. DOI: 10.1371/journal.pone.0006403

VOLKOVA, V. V.; BAILEY, R. H.; WILLS, R. W. Salmonella in broiler litter and properties of soil at farm location. Plos One, San Francisco, v. 4, n. 7, p. 1-9, 2009. DOI: 10.1371/journal.pone.0006403

VON RÜCKERT, D. A. S.; PINTO, P. S. A.; SANTOS, B. M.; MOREIRA, M. A. S.; RODRIGUES, A. C. A. Pontos críticos de controle de Salmonella spp. no abate de frangos. Arquivo Brasileiro Medicina Veterinária e Zootecnia, Botucatu, v. 61, n. 2, p. 326-330, 2009. DOI: 10.1590/S0102-09352009000200007

VOSS-RECH, D.; VAZ, C. L.; ALVES, L.; COLDEBELlA, A.; LEÃO, J. A.; RODRIGUES, D. P.; BACK, A. A temporal study of Salmonella enterica serotypes from broiler farms in Brazil. Poultry Science, Savoy, v. 94, n. 3, p. 433-441, 2015. DOI: $10.3382 /$ ps/ peu081

WORLD HEALTH ORGANIZATION / FOOD AND AGRICULTURE ORGANIZATION OF THE UNITED NATIONS - WHO/FAO. Salmonella and Campylobacter in chicken meat: meeting report. Microbiological risk assessment. Geneva: WHO PRESS, 2009. n. 19, 56 p. Available at: http:/www.fao.org/docrep/012/i1133e/ i1133e00.htm. Accessed at: 10 nov. 2015.

YANG, B.; QIAO, L.; ZHANG, X.; CUI, Y.; XIA, X.; CUI, S.; WANG, X.; MENG, X.; GE, W.; SHI, X.; WANG, D.; MENG, J. Serotyping, antimicrobial susceptibility, pulsed field gel electrophoresis analysis of Salmonella isolates from retail foods in Henan Province, China. Food Control, Vurrey, v. 32, n. 1, p. 228-235, 2013. DOI: 10.1016/j.foodcont.2012.11.022

ZAIDI, M. B.; MCDERMOTT, P. F.; FEDORKACRAY, P.; LEON, V.; CANCHE, C.; HUBERT, S. K.; ABBOTT, J.; LEON, M.; ZHAO, S.; HEADRICK, M.; TOLLEFSON, L. Nontyphoidal Salmonella from human clinical cases, asymptomatic children, and raw retail meats in Yucatan, Mexico. Clinical Infection Disease, Oxford, v. 42, n. 1, p. 21-28, 2006. DOI: 10.1086/498508 
